\title{
PERAN PESANTREN DALAM MENGEMBANGKAN ISLAM MODERAT DI INDONESIA
}

\section{THE ROLE OF PESANTREN IN DEVELOPING MODERATE \\ ISLAM IN INDONESIA}

\author{
Abdillah \\ UIN SGD Bandung \\ abdillahagung05@gmail.com
}

\begin{abstract}
ABSTRAK
Pesantren adalah lembaga pendidikan agama Islam tertua di Indonesia. Belakangan Pesantren mendapat stigma buruk terutama dari media Barat yang menuduh Pesantren sebagai sarang radikalisme dan terorisme. Hal ini sangat bertentangan dengan misi Pesantren, membawa misi untuk mengembangkan Islam moderat, Islam yang menjadi berkah bagi semua alam. Dalam artikel ini, penulis ingin membuktikan bahwa pemikiran Pesantren masih sama dengan sejak didirikan dan juga ingin membuktikan bahwa tuduhan dari media Barat tidak benar. Pada artikel ini, penulis menggunakan metode tinjauan pustaka. Dari hasil penelitian ini, penulis menemukan bahwa pesantren sejak dulu hingga saat ini masih mengajarkan Islam yang inklusif, terbuka, dan moderat. Oleh karena itu, hasil ini juga menolak tuduhan Barat terhadap pesantren.
\end{abstract}

Kata kunci: Pesantren Tradisional (Salaf), toleransi, Islam moderat

\section{ABSTRACT}

Pesantren is the oldest Islamic religious education institution in Indonesia. Lately Pesantren has gotten a bad stigma especially from Western media that accused Pesantren as a nest of radicalism and terrorism. This is very contrary to the mission of the pesantren carrying the mission to develop moderate Islam, Islam which is a blessing for all nature. In this article, the author wants to prove that the pesantren's thinking is still the same as since its inception and also wants to prove that the accusation from Western media is not true. In this article, authors use the literature review method. From the results of this study, the authors found that pesantren since the past until today still teaches an inclusive, open and moderate Islam. Therefore, these results also rejected Western accusations towards pesantren.

Keywords: Traditional Pesantren (Salaf), tolerance, moderate Islam 


\section{PENDAHULUAN}

Indonesia merupakan sebuah negara dengan mayoritas Muslim terbesar di dunia. Hari ini, penduduk Indonesia berjumlah lebih dari 255 juta jiwa yang 87,2 persen diantaranya adalah Muslim dan sisanya adalah umat agama lain yang terdiri dari Kristen, Hindu, Budha, Konghucu maupun keyakinan lokal lainnya. ${ }^{1}$ Oleh sebab itu, dalam konteks Indonesia, pendidikan toleransi, kesadaran akan kemajemukan maupun pendidikan yang menghasilkan peserta didik yang berpandangan inklusif, sangat penting untuk diwujudkan.

Indonesia, berbeda dengan kebanyakan negara lainnya yang memiliki kemajemukan yang bukan hanya bersifat beragam etnis, suku, dan agama, tapi juga beragam budaya. Kemajemukan tersebut pada satu sisi merupakan kekuatan sosial dan keragaman yang indah apabila satu sama lain bisa saling bersinergi dan bekerja sama untuk membangun

${ }^{1}$ Robert W Hefner, "Christians, Conflict, and Citizenship in Muslim- Majority Indonesia," The Review of Faith \& International Affairs 15:1, no. March (2017): 91-101. bangsa. Namun, pada sisi lain, kemajemukan tersebut apabila tidak dikelola dengan tepat dan baik akan menjadi pemicu dan penyulut konflik serta kekerasan yang dapat menggoyahkan sendi-sendi kehidupan berbangsa dan bernegara. Peristiwa Ambon dan Poso misalnya, merupakan contoh paling riil yang menunjukkan bahwa kekerasan dan konflik horizontal sudah pernah terjadi, bahkan konflik ini telah menguras energi dan merugikan jiwa, materi dan juga mengorbankan keharmonisan di antara sesama masyarakat Indonesia. ${ }^{2}$

Agama ataupun keyakinan tertentu seringkali dituding sebagai faktor pemicu kenapa seseorang melakukan kekerasan terhadap orang lain. Padahal agama dalam hal ini tidak hanya bisa dijadikan sebagai faktor disintegratif (disintegrative factor) tapi juga faktor pemersatu (integrative factor) $^{3}$ Agama bisa dilihat sebagai faktor pemersatu ketika mampu mempersatukan

2 Ali Maksum, "Model Pendidikan Toleransi Di Pesantren Modern Dan Salaf," Jurnal Pendidikan Agama Islam 03, no. 01 (2015): 81-108.

${ }^{3}$ Afif Muhammad, Agama Dan Konflik Sosial: Studi Pengalaman Indonesia, 2012. 
kelompok manusia dari seluruh belahan dunia tanpa melihat asal usul suku, budaya maupun bahasa. Faktor ini menembus perbedaan batas-batas geografis, kesukuan, maupun perbedaan sosial lainnya. Sebaliknya, agama juga bisa menjadi faktor pemisah atau disintegratif ketika dipaksa memeluk maupun beribadah sesuai dengan aturan agama lain. Jika hal ini dilakukan maka akan memicu munculnya gesekan dan konflik yang sulit dihindarkan.

Konflik serius yang pernah muncul, terjadi sejak Indonesia memasuki era reformasi di tahun tahun 1998. Sejak itu, muncul berbagai kelompok dan organisasi Islam radikal yang semasa orde baru tidak berikan ruang gerak. Momentum inilah yang kemudian dijadikan kesempatan bagi kelompok-kelompok radikal untuk bangkit dan menggerakkan kembali pemikirannya mengingat era reformasi yang terjadi, memang memberikan ruang yang luas dan bebas untuk semua orang bergerak.

Dalam situasi seperti ini, kelompok Islam radikal dan konservatif mengorganisir penyerangan terhadap kelompok minoritas. Mereka mengancam, membakar gereja dan tempat ibadah pemeluk agama lain. Konflik tersebut tidak hanya terjadi antarkelompok agama, tapi juga di antara sesama anggota kelompoknya seperti penyerangan yang terjadi pada kelompok Ahmadiyah dan Syi'ah di beberapa wilayah di Indonesia. ${ }^{4}$

Bagaimanapun juga, keadaan seperti ini telah memunculkan konsekuensi berupa kekerasan dan konflik yang tidak bisa hindarkan. Masalah yang muncul setelah era reformasi menurut Syamsun Ni'am disebabkan oleh tiga masalah utama. Pertama, kurangya rasa nasionalisme. Kedua, hilangnya rasa persaudaraan sebangsa, hilangnya sikap menghargai dan menghormati sesama dan hilangnya kerja sama antarsesama. Ketiga, masalah pemahaman keagamaan yang tidak komprehensif (käffah). Pemahaman ini berimplikasi pada pemahaman keagamaan yang eksklusif dan muncul pemahaman untuk

\footnotetext{
${ }^{4}$ Noorhaidi Hasan, "RELIGIOUS DIVERSITY AND BLASPHEMY LAW Understanding Growing Religious Conflict And" 55, no. 1 (2017): 105-26, https://doi.org/10.14421/ajis.2017.551.105126.
} 
menghilangkan orang lain yang berbeda pendapat maupun beda keyakinan. ${ }^{5}$

Berdasarkan masalah yang sudah dipaparkan, maka penulis akan menguraikan dan menjelaskan mengenai pemikiran yang terbuka dan inklusif dari komunitas pesantren sekaligus juga menyanggah bahwa pesantren secara umum tidak pernah terlibat langsung dalam berbagai tindakan radikal dan intoleran.

\section{METODE PENELITIAN}

Dalam kajian ini, penulis menggunakan metode tinjauan literatur yang berkaitan dengan pesantren. Hal pertama yang dilakukan penulis adalah mengumpulkan beberapa literatur baik berupa buku, artikel, dan dokumen lainnya yang berkaitan dengan pemikiran keagamaan komunitas pesantren. Setelah bahan terkumpul, selanjutnya penulis melakukan analisis dokumen.

${ }^{5}$ Syamsun Ni'am, "Pesantren : The Miniature of Moderate Islam in Indonesia," Indonesian Journal of Islam and Muslim Societis 5, no. 1 (2015): 111-34.

\section{HASIL DAN PEMBAHASAN}

Makna Pesantren

Secara harfiah,

kata "Pesantren" berasal dari kata santri yang diartikan sebagai orang yang belajar agama Islam. Sementara secara etimologis, kata "pesantren" mendapatkan imbuhan awal pe-dan akhiran -an yang berarti tempat santri; asrama tempat santri belajar agama; atau pondok. Dengan demikian, pesantren bisa diartikan sebagai tempat orang berkumpul untuk belajar agama Islam. ${ }^{6}$

Arti yang sama juga disampaikan oleh Umma Farida. Menurutnya, pesantren secara etimologis berasal dari kata pesantri-an yang berarti tempat santri, dan secara fungsional dapat didefinisikan sebagai sebuah institusi yang memiliki fungsi sebagai tempat pendidikan, dakwah, kemasyarakatan dan bahkan pada masa penjajahan juga berfungsi perjuangan. ${ }^{7}$

\footnotetext{
${ }^{6}$ Syamsun Ni'am.

${ }^{7}$ Umma Farida, "Radikalisme, ModeRatisme, Dan LibeRalisme Pesantren: Melacak Pemikiran Dan Gerakan Keagamaan Pesantren Di Era Globalisasi," Edukasia: Jurnal Penelitian Pendidikan Islam 10, no. 1 (2015): 145-64.
} 
Sementara itu, secara terminologis, pondok pesantren merupakan institusi sosial keagamaan yang menjadi wahana pendidikan bagi umat Islam yang ingin mendalami ilmu-ilmu keagamaan. Pondok pesantren dalam terminologi keagamaan merupakan institusi pendidikan Islam. Meskipun demikian, pesantren kemudian berkembang sebagai ikon sosial yang memiliki pranata sosial di tengahtengah masyarakat. Hal ini karena pondok pesantren memiliki modalitas sosial yang khas, yaitu: 1) ketokohan kyai, 2) santri, 3) independen dan mandiri, dan 4) jaringan sosial yang kuat antaralumni pondok pesantren. ${ }^{8}$

Selanjutnya, Nurcholish Madjid memahami pesantren atau pondok sebagai lembaga yang bisa disebut sebagai wujud proses perkembangan sistem pendidikan nasional. Jika ditilik dari sisi historisnya, pesantren tidak hanya identik dengan makna keislaman, tetapi juga mengandung makna keaslian Indonesia (indigenous). Sebab, lembaga yang serupa

${ }^{8}$ Syamsun Ni'am, "Pesantren: The Miniature of Moderate Islam in Indonesia." pesantren ini sebenarnya sudah ada sejak pada masa kekuasaan HinduBuddha. Sehingga Islam tinggal meneruskan dan mengislamkan lembaga pendidikan yang sudah ada. $^{9}$

\section{Memahami Islam Moderat}

Perkembangan Islam di Indonesia tidak terlepas dari sejarah masuknya Islam ke Nusantara. Hal ini bisa dikaji berdasarkan beberapa teori tentang masuknya Islam ke Nusantara. Berdasarkan teori yang paling populer menyatakan bahwa Islam di Indonesia pertama kali muncul dibawa oleh para ulama sufi yang kemudian berkembang dan dilanjutkan oleh Walisongo yang merupakan golongan ulama sufi yang mampu mengakomodasi berbagai perbedaan yang ada di Nusantara.

Islam yang diajarkan oleh Walisongo adalah Islam yang moderat. Hal ini dapat disaksikan dari bagaimana Walisongo menyebarkan Islam dengan damai, tidak memaksa dan menyerang orang lain agar masuk Islam, menghargai budaya dan bahkan mengakomodasi

\footnotetext{
${ }^{9}$ Maksum, "Model Pendidikan Toleransi Di Pesantren Modern Dan Salaf."
} 
Abdillah $\quad$ Peran Pesantren dalam...

budaya tanpa menghilangkan identitas. ${ }^{10}$ Walisongo datang ke Nusantara dengan cara yang damai. Mereka tidak mengganggu tradisi dan adat lokal dan bahkan mereka menjadikan budaya sebagai alat untuk berdakwah. Disebabkan hal tersebut, maka Islam di Indonesia adalah Islam yang khas yang menyatu dan mengakomodasi budaya lokal namun tidak menghilangkan identitasnya. Istilah Islam moderat (washathiyah) yang pada prinsipnya berlandaskan pada hadist Nabi dan juga Alquran.

Selanjutnya, istilah moderat (washathiyah) ini digunakan untuk mencari jalan tengah antara modernisme maupun liberalisme dan fundamentalisme.

Dialektika modernisme dan fundamentalisme tidak hanya terjadi dalam Islam, tapi juga dalam agama Kristen. Istilah modernisme pada awalnya diartikan sebagai aliran kegamaan yang melakukan interpretasi terhadap doktrin agama agar sesuai dengan perkembangan pemikiran modern. Sebaliknya, fundamentalisme justru dianggap sebagai aliran yang tetap

${ }^{10}$ Syamsun Ni'am, 'Pesantren : The Miniature of Moderate Islam in Indonesia." berpegang teguh terhadap "fundamen" agama Kristen melalui interpretasi yang kaku dan literal. ${ }^{11}$

Kemunculan istilah Islam moderat ini dianggap sebagai wacana yang strategis guna mencegah penyebarluasan paham fundamentalisme atau radikalisme agama sekaligus juga menolak paham liberalisme yang dirasakan merupakan ancaman terhadap Islam itu sendiri. Kedudukannya tentu dijadikan sebagai jalan tengah di antara ekstrim kanan maupun kiri. Selanjutnya, Abou Fadl sebagaimana dikutip oleh Chafid Wahyudi menyatakan bahwa Islam moderat adalah mereka yang meyakini Islam, menghormati kewajiban-kewajiban kepada Tuhan, dan meyakini bahwa Islam sesuai untuk setiap saat dan zaman, li kull zamân wa makân. Mereka tidak memperlakukan agama laksana monumen yang baku, tetapi memperlakukannya dalam kerangka iman yang dinamis dan aktif. Konsekuensinya, Islam moderat menghargai pencapaian-pencapaian

\footnotetext{
${ }^{11}$ Chafid Wahyudi, "TIPOLOGI ISLAM MODERAT DAN PURITAN: PEMIKIRAN KHALED M. ABOU EL-FADL," Teosofi: Jurnal Tasawuf Dan Pemikiran Islam 1, no. 1 (2011).
} 
sesama Muslim di masa silam, untuk direaktualisasikan konteks kekinian. ${ }^{12}$

Opini ini sesuai dengan pendapat Quraish Shihab yang menyatakan bahwa perbedaan adalah sebuah keharusan dalam hidup yang diinginkan oleh Allah yang Mahakuasa. Dimana perbedaan pendapat biasa terjadi dalam bidang sains, dan bahkan perbedaan respon manusia pada kebenaran Alquran, interpretasi terhadapnya maupun bentuk prakteknya. ${ }^{13}$ Lebih lanjut, penulis menyandingkan Islam moderat dengan Islam inklusif. Paham inklusif adalah pandangan keberagamaan yang didasarkan pada pandangan bahwa agama-agama lain yang ada di dunia ini mengandung kebenaran dan dapat memberikan manfaat serta keselamatan bagi penganutnya. Selain itu, ia tidak semata-mata menunjukkan realitas tentang adanya kemajemukan, melainkan terlibat aktif terhadap kenyataan kemajemukan.

Sebaliknya, Islam eksklusif adalah

12 Ibid.,

${ }^{13}$ M. Quraish Shihab, Secercah Cahaya Ilahi: Hidup Bersama al-Qur'an, Bandung: Mizan, 2007, 52 suatu pandangan yang menganggap bahwa satu agama adalah benar dan yang lain sesat atau salah. ${ }^{14}$

\section{Pemahaman \\ Pesantren}

Keagamaan

Sistem nilai yang dianut oleh kalangan pesantren adalah yang berakar dalam agama Islam. Tetapi tidak semua yang berakar dalam agama itu digunakan oleh mereka. Kalangan pesantren sendiri, menamakan sistem nilai yang digunakannya itu dengan dengan sebutan "Ahlu Sunnah wal Jama'ah". ${ }^{15}$ Ahlu Sunnah wal Jamâ'ah sendiri mengacu pada golongan Sunni. Dimana ilmu ketuhanan, kalam, atau tauhid yang ada di pesantren mengikuti Mazhab Sunni, sebagaimana yang dirumuskan oleh Abu Hassan alAsy'ârî, dan dalam beberapa karyakarya Imam Ghazâlî yang telah tersebar luas. ${ }^{16}$

Ideologi Ahlu sunnah wal Jama'ah di Indonesia sudah lama

\footnotetext{
${ }^{14} \mathrm{P}$ Goldburg, "Religious Diversity and Religious Literacy," Learning to Teach in the Primary School 50, no. 1 (2013): 20824, https://doi.org/10.1023/A:1012058201981. ${ }^{15}$ Nurcholish Madjid, Bilik-Bilik Pesantren (Jakarta: Paramadina, 1997).

16 Ibid.,
} 
diajarkan oleh komunitas pesantren. Pesantren sejak awal berdirinya sudah mengikuti paham Sunni. Seperti yang sudah diketahui bahwa ajaran Sunni atau Ahlu sunnah wal Jama'ah di Indonesia muncul karena jasa dari Wali Songo. Oleh sebab itu, karakter dasar pesantren dari awal berdirinya memiliki ciri-ciri berikut:

1) Tawassut atau tidak memihak atau moderasi, 2) Tawazun atau menjaga keseimbangan dan harmoni, 3) Tasammuh atau toleransi, 4) Tashawwur atau musyawarah, 5) Adl atau bersikap adil dalam beraksi ataupun bereaksi.

Pesantren mempunyai sikap konsisten dalam menjalankan ajaran Islam secara substantif dan inklusifhumanis sesuai kondisi lokalitaskultural Islam Indonesia yang damai, ${ }^{2}$ sebagai agama rahmatan $l i$ al- 'alamin dan visi jauh ke depannya dalam rangka menciptakan perdamaian antarsesama manusia dan toleran terhadap berbagai macam perbedaan. ${ }^{17}$

${ }^{17}$ Mukhibat, "Deradikalisasi Dan Integrasi Nilai-Nilai Pluralitas Dalam Kurikulum Pesantren Salafi Haraki Di Indonesia," AlTahrir: Jurnal Pemikiran Islam 14, no. 1 (2016): 181-204, https://doi.org/10.21154/al-tahrir.v14i1.121.
Sementara itu, pemahaman moderat tentang Islam di Indonesia juga dapat merujuk pada penyebaran Islam yang dilakukan oleh para ulama Sufi atau yang dikenal sebagai "Walisongo" sebagaimana yang telah dijelaskan sebelumnya. Pembawa generasi Islam moderat di Indonesia mungkin bisa merujuk pada praktik Islam melalui organisasi Islam seperti Muhammadiyah sebagai "Lembaga sosial dan pendidikan", dan NU (Nahdlatul 'Ulama) melalui pendidikan di Pesantren. Islam dalam konteks Indonesia jenis ini lebih cocok, dengan meminjam konsep Syafi'i Ma'arif sebagaimana dikutip oleh Syamsun Ni'am disebut "Islam dalam Bingkai Indonesia".

Azyumardi Azra juga sering menyebutkan bahwa Islam moderat merupakan karakter asli umat Islam di Indonesia. Pesantren sebagai miniatur komunitas Muslim Indonesia telah menunjukkan karya mereka dalam mengartikulasikan Islam moderat di Indonesia. ${ }^{18}$

Pesantren yang selama ini dikembangkan oleh Walisongo mengikuti ideologi Ahl al-Sunnah

\footnotetext{
${ }^{18}$ Syamsun Ni'am, "Pesantren : The Miniature of Moderate Islam in Indonesia."
} 
wal Jama'ah atau Sunni.

Karakteristik dari ajaran dan ideologi

Sunni adalah moderat, toleran dan

terbuka. Sebagaimana telah

disebutkan bahwa dalam bidang

teologi, mereka mengikuti mazhab

Asy'ariyah dan Al-Maturidiyyah.

Kelompok ini tidak seperti

Mu'tazilah yang lebih

mengutamakan akal daripada wahyu

atau naql. Dalam bidang fiqh atau

hukum Islam mereka mengikuti

mazhab Imam Syafi' i. ${ }^{19}$

Komunitas pesantren atau masyarakat Islam tradisional identik dengan masyarakat NU (Nahdlatul Ulama) yang tentu saja tidak dapat dilepaskan dari pesantren "salaf" sebagai rujukan praktik beragama. Sikap golongan Islam tradisional yang diwakili NU, pada dasarnya tidak terlepas dari akidah Ahlu Sunnah wa al-Jama'ah (Aswaja) yang dapat disebut paham moderat. Pemikiran Aswaja sangat toleran terhadap pluralisme pemikiran. Berbagai pemikiran yang tumbuh dalam masyarakat muslim mendapatkan pengakuan yang

${ }^{19}$ Zamakhsyari Dhopier, Tradisi Pesantren: Studi Pandangan Hidup Kyai Dan Visinya Mengenai Masa Depan Indonesia (Jakarta: LP3ES, 2015). apresiatif. Dalam hal ini Aswaja sangat responsif terhadap hasil pemikiran berbagai mazhab yang masih eksis di tengah-tengah masyarakat seperti Mazhab Hanafi, Maliki, Syafi'i, dan Hanbali. Melainkan juga terhadap mazhabmazhab yang pernah lahir, seperti imam Daud al-Zhahiri, Imam Abdurrahman al-Auza'i, Imam Sufyan al-Tsauri, dan lain-lain. ${ }^{20}$

Sangat menarik untuk dilihat dengan jelas bahwa pemikiran ulama pesantren tentu toleran, terbuka, moderat dan menghargai perbedaan selama pengikut Ahl Sunnah wa alJamā'ah mempertahankan dan mengembangkan prinsip-prinsip seperti at-Tawāsut, at-tawazun, dan at-tasāmuh. Atas dasar penjelasan di atas, maka Islam di Indonesia adalah Islam yang moderat dan ini menjadi karakteristik dari Islam Indonesia yang toleran, menghargai perbedaan, dan melindungi minoritas. Karena pemikiran pesantren yang moderat dan terbuka, maka dengan jelas hal ini juga menolak dan menggugurkan semua stigma buruk tentang pesantren yang dituduhkan oleh

\footnotetext{
${ }^{20}$ Maksum, "Model Pendidikan Toleransi Di Pesantren Modern Dan Salaf."
} 
Abdillah $\quad$ Peran Pesantren dalam...

media Barat maupun pembuatan kebijakan Barat.

Berikut ini penulis berikan gambaran tentang pola pemikiran komunitas pesantren:

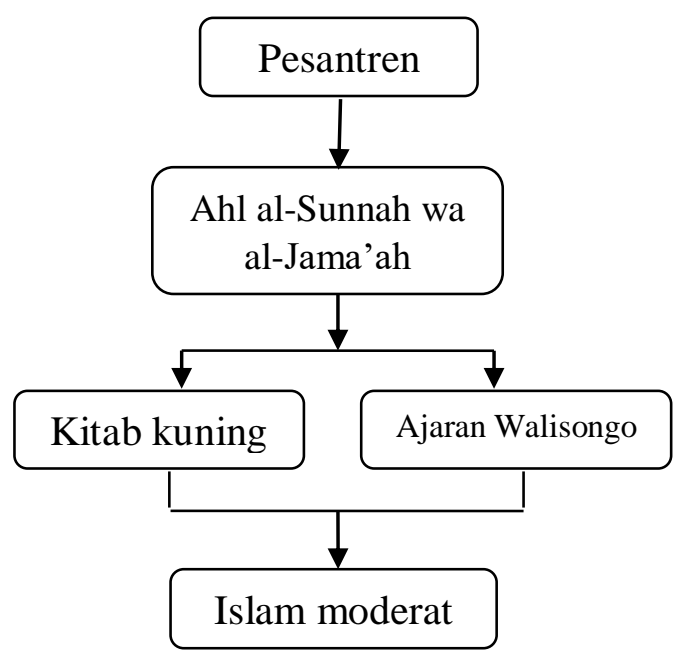

\section{SIMPULAN}

Berdasarkan tulisan di atas, dapat disimpulkan bahwa pesantren selama ini selalu menjadi kambing hitam dan disalahkan oleh media Barat, terutama semenjak peristiwa bom bunuh diri di Amerika. Semenjak peristiwa pengeboman tersebut, Amerika dengan gencar menyerang Islam sebagai dalang terorisme. Rangkaian serangan
Amerika terhadap terorisme dimulai dengan menyisir negara-negara di Timur Tengah sampai ke Indonesia. sementara itu, di Indonesia sendiri, ada banyak kasus intoleransi dan terorisme yang muncul dan bahkan menyebar di beberapa wilayah di Indonesia.

Namun, dalam kajian ini, penulis membuktikan bahwa tuduhan Barat tidak sesuai dengan kenyataan yang terjadi. Pesantren sebagai lembaga pendidikan Islam tertua di Indonesia masih memiliki paham yang toleran, terbuka dan moderat masih sama seperti awal kemunculannya.

Paham moderat yang ditunjukkan oleh pesantren tidak lepas dari paham keagamaan dan ideologi yang mereka ikuti. Ahlu Sunnah wa al-Jama'ah yang merupakan sebuah ideologi yang mengajarkan tentang toleransi dan menerima pluralitas. Paham ini sangat sesuai dengan keadaan bangsa Indonesia yang majemuk baik dalam suku, budaya, adat maupun keyakinan.

\section{DAFTAR PUSTAKA}


Jurnal Yaqzhan : Analisis Filsafat, Agama dan Kemanusiaan|

Vol 5, No 2, Desember 2019

Afif Muhammad. Agama Dan Konflik Sosial: Studi Pengalaman Indonesia, 2012.

Chafid Wahyudi. "TIPOLOGI ISLAM MODERAT DAN PURITAN: PEMIKIRAN KHALED M. ABOU ELFADL." Teosofi: Jurnal Tasawuf Dan Pemikiran Islam 1, no. 1 (2011).

Farida, Umma. "Radikalisme, ModeRatisme, Dan LibeRalisme Pesantren: Melacak Pemikiran Dan Gerakan Keagamaan Pesantren Di Era Globalisasi." Edukasia: Jurnal Penelitian Pendidikan Islam 10, no. 1 (2015): 145-64.

Goldburg, P. "Religious Diversity and Religious Literacy." Learning to Teach in the Primary School 50, no. 1 (2013): 208-24. https://doi.org/10.1023/A:10120 58201981.

Hasan, Noorhaidi. "RELIGIOUS DIVERSITY AND BLASPHEMY LAW Understanding Growing Religious Conflict And" 55, no. 1 (2017): 105-26. https://doi.org/10.14421/ajis.20 17.551.105-126.

Hefner, Robert W. "Christians, Conflict, and Citizenship in Muslim- Majority Indonesia." The Review of Faith \& International Affairs 15:1, no. March (2017): 91-101.

Madjid, Nurcholish. Bilik-Bilik Pesantren. Jakarta: Paramadina, 1997.

Maksum, Ali. "Model Pendidikan
Toleransi Di Pesantren Modern Dan Salaf." Jurnal Pendidikan Agama Islam 03, no. 01 (2015): 81-108.

Mukhibat. "Deradikalisasi Dan Integrasi Nilai-Nilai Pluralitas Dalam Kurikulum Pesantren Salafi Haraki Di Indonesia." AlTahrir: Jurnal Pemikiran Islam 14, no. 1 (2016): 181-204. https://doi.org/10.21154/altahrir.v14i1.121.

Syamsun Ni'am. "Pesantren: The Miniature of Moderate Islam in Indonesia." Indonesian Journal of Islam and Muslim Societis 5, no. 1 (2015): 111-34.

Zamakhsyari Dhopier. Tradisi Pesantren: Studi Pandangan Hidup Kyai Dan Visinya Mengenai Masa Depan Indonesia. Jakarta: LP3ES, 2015. 